Article

\title{
Structure Elucidation and in Vitro Toxicity of New Azaspiracids Isolated from the Marine Dinoflagellate Azadinium poporum
}

\section{Bernd Krock ${ }^{1, *}$, Urban Tillmann ${ }^{1}$, Éric Potvin ${ }^{2}$, Hae Jin Jeong ${ }^{3}$, Wolfgang Drebing ${ }^{1}$,} Jane Kilcoyne ${ }^{4}$, Ahmed Al-Jorani ${ }^{5}$, Michael J. Twiner ${ }^{5}$, Qun Göthel ${ }^{1}$ and Matthias Köck ${ }^{1, *}$

1 Alfred-Wegener-Institut, Helmholtz-Zentrum für Polar- und Meeresforschung, Am Handelshafen 12, Bremerhaven 27570, Germany; E-Mails: urban.tillmann@awi.de (U.T.); wolfgang.drebing@awi.de (W.D.); qgothel@jausoft.com (Q.G.)

2 Division of Polar Ocean Environment, Korea Polar Research Institute, Incheon 406-840, Korea; E-Mail: ericpotvin@kopri.re.kr

3 School of Earth and Environmental Science, Seoul National University, Seoul 151-747, Korea; E-Mail: hjjeong@snu.ac.kr

4 Marine Institute, Rinville, Oranmore, Co. Galway, H91 R673, Ireland;

E-Mail: jane.kilcoyne@marine.ie

5 Department of Natural Sciences, University of Michigan, Dearborn, MI 48202, USA; E-Mails: ahmed_aljorany@yahoo.com (A.A.-J.); mtwiner@med.wayne.edu (M.J.T.)

* Authors to whom correspondence should be addressed; E-Mails: Bernd.Krock@awi.de (B.K.); Matthias.Koeck@awi.de (M.K.); Tel.: +49-471-4831-2055 (B.K.); +49-471-4831-1497 (M.K.); Fax: +49-471-4831-2115 (B.K. \& M.K.).

Academic Editor: Orazio Taglialatela-Scafati

Received: 14 April 2015 / Accepted: 14 October 2015 / Published: 30 October 2015

Abstract: Two strains of Azadinium poporum, one from the Korean West coast and the other from the North Sea, were mass cultured for isolation of new azaspiracids. Approximately $0.9 \mathrm{mg}$ of pure AZA-36 (1) and $1.3 \mathrm{mg}$ of pure AZA-37 (2) were isolated from the Korean $(870 \mathrm{~L})$ and North Sea $(120 \mathrm{~L})$ strains, respectively. The structures were determined to be 3-hydroxy-8-methyl-39-demethyl-azaspiracid-1 (1) and 3-hydroxy-7,8-dihydro-39demethyl-azaspiracid-1 (2) by ${ }^{1} \mathrm{H}$ - and ${ }^{13} \mathrm{C}-\mathrm{NMR}$. Using the Jurkat $\mathrm{T}$ lymphocyte cell toxicity assay, (1) and (2) were found to be 6- and 3-fold less toxic than AZA-1, respectively.

Keywords: shellfish poisoning; lipophilic marine biotoxins; NMR 


\section{Introduction}

The first azaspiracid poisoning (AZP) event was recorded in 1995 after eight people experienced severe gastrointestinal disorders following consumption of mussels originating from the Irish West Coast. Symptoms were typical of diarrhetic shellfish poisoning (DSP). Even though the mouse bioassay for DSP toxicity was also strongly positive, no DSP toxins could be detected at elevated levels and thus could not account for the observed severe intoxications [1].

In 1998, the causative compound was isolated and characterized from shellfish and subsequently named azaspiracid-1 (AZA-1) according to its structural properties [2]. A few years later, the synthesis of AZA-1 led to its structural revision [3]. AZAs are polyketides consisting of highly hydroxylated linear carbon chains that are cyclized at several points by formation of ether bridges. In addition, AZAs typically contain a six-membered cyclic imine ring [2,3].

After AZAs were confirmed to be responsible for gastrointestinal disorders associated with the consumption of seafood, further AZP incidents were reported from France and Italy [4]. To date, there are no systematic global surveys on the geographical distribution of AZAs but there are several reports of shellfish contaminated with AZAs, such as from the East coast of England and along the Norwegian West Coast [5], Portugal [6], Morocco [7], Chile [8], Japan [9] and China [10]. In contrast, monitoring of lipophilic phycotoxins in mussels from the White Sea (Russia) did not indicate the presence of AZAs [11]. More than two dozen naturally occurring structural variants of AZA-1 have been described [12]. Although most research has focused on AZA-1 as the first discovered and most accessible AZA analogue, other structural variants have been isolated and characterized from shellfish [13-16].

In 2007, an AZA-producing organism was isolated [17] and identified as Azadinium spinosum [18]. Bulk culturing of this organism was performed with subsequent isolation of AZA-1, -2 [19], -33 and -34 and description of AZA-35 [20]. In addition to A. spinosum, a number of new species of the genus Azadinium were described from the North Sea: A. obesum [21], A. poporum [22], and A. polongum [23]. A species designated as A. cf. spinosum was reported to form blooms at the Argentinean shelf [24], A. dexteroporum was described from the Mediterranean [25], A. dalianense from the coast of China [26], and more recently three new species have been described from the Irminger Sea (North Atlantic) [27]. In addition to the European strains of A. poporum, there also exists a strain from Korean coastal waters [28] and a number of strains from China [29]. Based on minor differences in shape of the $3^{\prime}$ plate and variability in ribosomal DNA sequences between the Korean and the European strains, the Korean isolate was initially designated as $A$. cf. poporum. However, this trait was subsequently shown to vary among and within other Asian A. poporum strains [29], which supports the notion that $A$. poporum from Europe and Asia, despite their differences in ITS and 28S gene sequences [29], are conspecific. Most species of the genus Azadinium were originally described as non-AZA producers [21-23,26]. However, in various strains of $A$. poporum we recently detected compounds that show fragmentation patterns with high similarities to those of AZAs. Based on collision induced dissociation (CID) spectra and high resolution mass spectral analysis, putative molecular structures for these new toxins were proposed [30].

In this study, the structures of these compounds were verified using nuclear magnetic resonance (NMR) spectroscopy and their in vitro potencies were obtained using the Jurkat T lymphocyte cell assay. 


\section{Results}

\subsection{Purification of $A Z A-36$ (1) and $A Z A-37$ (2)}

We purified AZA-36 (1) and AZA-37 (2) from two strains of A. poporum, one from the Western Pacific [28] and the other from the North Sea [22] using procedures previously described [19]. Four isolation steps were required to purify (1) from the HP20 extracts (Table 1). For (1) a relatively high amount of culture $(870 \mathrm{~L})$ was needed for a final yield of $0.89 \mathrm{mg}$, because the toxin cell quota of the Korean strain of $A$. poporum with $\sim 2 \mathrm{fg} \cdot \mathrm{cell}^{-1}$ was relatively low [30].

Table 1. Batch summary table for purification of AZA-36 (1).

\begin{tabular}{ccccc}
\hline Step No & Step & AZA-36 [mg] & Weight [g] & Purity [\%] $^{\dagger}$ \\
\hline & HP20 resin extract & 1.30 & 8.30 & $<0.1$ \\
1 & Ethyl acetate partitioning & 1.20 & 0.74 & 0.2 \\
2 & Silica gel & 1.05 & 0.18 & 0.6 \\
3 & Flash (phenyl-hexyl) & 0.92 & $<0.01$ & 40.0 \\
4 & Prep HPLC (C18) & 0.89 & - & $>95$ \\
& \% Recovery (steps 1-4) & 69 & & \\
\hline
\end{tabular}

$\dagger$ Based on w/w.

In contrast to the Korean strain, the North Sea strain had an approximately tenfold (2) cell quota of $\sim 20 \mathrm{fg} \cdot \mathrm{cell}^{-1}$ [30] and thus only $120 \mathrm{~L}$ of culture were needed to give a final amount of $1.28 \mathrm{mg}$ pure (2) (Table 2).

Table 2. Batch summary table for purification of AZA-37 (2).

\begin{tabular}{ccccc}
\hline Step No & Step & AZA-37 [mg] & Weight [g] & Purity [\%] $^{\dagger}$ \\
\hline \multirow{5}{*}{1} & HP20 resin extract & 1.70 & 1.03 & 0.2 \\
2 & Silica gel & 1.60 & 0.25 & 0.6 \\
3 & Flash (phenyl-hexyl) & 1.57 & 0.01 & 20.0 \\
& Prep HPLC (C18) & 1.28 & - & $>95$ \\
\hline \% Recovery (steps 1-3) & 75 & & \\
\multicolumn{5}{c}{${ }^{\dagger}$ Based on w/w. }
\end{tabular}

\subsection{Structure Elucidation of AZA-36 (1) and AZA-37 (2)}

The chemical shifts $\left({ }^{1} \mathrm{H}\right.$ and $\left.{ }^{13} \mathrm{C}\right)$ of (1) and (2) are listed in Table 3. The corresponding spectra are given as supplementary material. Compared to AZA-1, the ${ }^{1} \mathrm{H}-\mathrm{NMR}$ spectrum of (1) (Table 3) showed an extra oxymethine signal at $\delta 4.43$, an allylic methyl signal at $\delta 1.70$, and the loss of the 39-methyl signal. The ${ }^{1} \mathrm{H},{ }^{1} \mathrm{H}-\mathrm{COSY}$ correlations between $\mathrm{H}-2 / \mathrm{H}-3$ and $\mathrm{H}-3 / \mathrm{H}-4$ confirmed the neighborhood of $\mathrm{H}-2$ and $\mathrm{H}-4$ to the oxymethine $(\mathrm{H}-3)$. The ${ }^{13} \mathrm{C}$ signal of $\mathrm{C}-3$ at $\delta 71.4$ indicated that $\mathrm{C}-3$ of $(\mathbf{1})$ was substituted by a hydroxyl group. The ${ }^{1} \mathrm{H},{ }^{13} \mathrm{C}-\mathrm{HMBC}$ spectrum showed correlations from $\mathrm{H}-47(\delta 1.70)$ to C-7 (123.4), C-8 (132.1), and C-9 (41.1), and the ${ }^{1} \mathrm{H},{ }^{1} \mathrm{H}-\mathrm{COSY}$ spectrum showed correlations between H-47/H-7 $(\delta 5.36)$ and H-47/H-6 ( $\delta$ 4.79). These correlations allowed the assignment of the new allylic methyl group. Moreover, the methyl group at C-39 was substituted by a proton according to the 
${ }^{1} \mathrm{H},{ }_{1} \mathrm{H}-\mathrm{COSY}$ spectrum. The other subunits in (1) were assigned on the basis of the $1 \mathrm{D}$ and 2D NMR experiments. Based on these results, the structure of AZA-36 was deduced to be 3-hydroxy-8-methyl-39-demethyl-azaspiracid-1 (1), as shown in Figure 1.

Table 3. ${ }^{1} \mathrm{H}$ - and ${ }^{13} \mathrm{C}-\mathrm{NMR}$ chemical shifts of AZA-36 (1) and AZA-37 (2).

\begin{tabular}{ccccccc}
\hline \multirow{2}{*}{ Atom No. } & \multicolumn{3}{c}{ AZA-36 } & \multicolumn{4}{c}{ AZA-37 } \\
\cline { 2 - 7 } & $\boldsymbol{\delta}_{\mathbf{C}}$ & \multicolumn{2}{c}{$\boldsymbol{\delta}_{\mathbf{H}}$} & \multicolumn{1}{c}{$\boldsymbol{\delta}_{\mathbf{C}}$} & $\boldsymbol{\delta}_{\mathbf{H}}$ \\
\hline 1 & $180.3^{\mathrm{a}}$ & - & - & $180.3^{\mathrm{a}}$ & - & - \\
2 & 46.0 & 2.34 & 2.39 & 46.1 & 2.33 & - \\
3 & 71.4 & 4.43 & - & 71.4 & 4.39 & - \\
4 & 135.5 & 5.75 & - & 134.6 & 5.70 & - \\
5 & 132.1 & 5.64 & - & 133.1 & 5.65 & - \\
6 & 72.8 & 4.79 & - & 73.3 & 4.35 & - \\
7 & 123.4 & 5.36 & - & 38.4 & 1.43 & 1.87 \\
8 & 132.1 & - & - & 22.2 & 1.70 & 1.77 \\
9 & 41.1 & 2.00 & 2.44 & 36.6 & 1.70 & 1.83 \\
10 & 108.3 & - & - & 109.1 & - & - \\
11 & 34.0 & 1.71 & 2.33 & 33.9 & 1.69 & 2.33 \\
12 & 38.3 & 1.99 & 2.18 & 32.8 & 1.83 & 2.03 \\
13 & 112.2 & - & - & 111.8 & - & - \\
14 & 32.1 & 2.02 & - & 31.8 & 2.01 & - \\
15 & 33.3 & 1.76 & 1.86 & 33.5 & 1.76 & 1.87 \\
16 & 78.9 & 3.91 & - & 78.9 & 3.94 & - \\
17 & 74.2 & 4.23 & - & 74.3 & 4.29 & - \\
18 & 37.5 & 1.99 & 2.06 & 37.6 & 2.00 & 2.07 \\
19 & 79.9 & 4.43 & - & 79.9 & 4.44 & - \\
20 & 77.5 & 3.90 & - & 77.4 & 3.93 & - \\
21 & 101.1 & - & - & 101.0 & - & - \\
22 & 37.8 & 2.06 & - & 37.6 & 2.07 & - \\
23 & 39.1 & 1.44 & 1.44 & 39.1 & 1.43 & 1.43 \\
24 & 43.0 & 1.35 & - & 43.0 & 1.35 & - \\
25 & 80.4 & 4.00 & - & 80.3 & 4.00 & - \\
26 & 149.0 & - & - & 149.0 & - & - \\
27 & 50.4 & 2.26 & 2.43 & 50.4 & 2.25 & 2.42 \\
28 & 99.4 & - & - & 99.4 & - & - \\
29 & 45.0 & 1.37 & 2.05 & 45.0 & 1.36 & 2.05 \\
30 & 27.2 & 2.23 & - & 27.2 & 2.23 & - \\
31 & 36.2 & 1.52 & 1.83 & 36.1 & 1.52 & 1.84 \\
32 & 73.7 & 4.37 & - & 73.7 & 4.37 & - \\
33 & 82.1 & 4.05 & - & 82.1 & 4.05 & - \\
34 & 75.7 & 4.99 & - & 75.7 & 5.00 & - \\
\hline & & & & & & \\
& & & - & -
\end{tabular}


Table 3. Cont.

\begin{tabular}{ccccccc}
\hline 35 & 42.8 & 2.49 & 2.61 & 42.7 & 2.49 & 2.60 \\
36 & 98.0 & - & - & 98.0 & - & - \\
37 & 37.5 & 1.99 & - & 36.7 & 1.98 & - \\
38 & 29.8 & 1.61 & 1.68 & 29.7 & 1.63 & 1.67 \\
39 & 23.8 & 1.70 & 1.81 & 23.8 & 1.70 & - \\
40 & 41.3 & 2.98 & 3.17 & 41.2 & 2.99 & 3.17 \\
41 & 17.5 & 0.94 & - & 17.5 & 0.90 & - \\
42 & 17.2 & 0.92 & - & 17.2 & 0.92 & - \\
43 & 18.9 & 0.84 & - & 18.9 & 0.84 & - \\
44 & 117.8 & 5.16 & 5.33 & 117.8 & 5.15 & 5.33 \\
45 & 24.3 & 0.96 & - & 24.3 & 0.96 & - \\
46 & 16.4 & 0.98 & - & 16.4 & 0.97 & - \\
47 & 23.0 & 1.70 & - & - & - & - \\
\hline
\end{tabular}

${ }^{a}$ Chemical shift value obtained from the ${ }^{1} \mathrm{H},{ }^{13} \mathrm{C}-\mathrm{HMBC}$ spectrum because the signal was not observed in the $1 \mathrm{D}^{13} \mathrm{C}$ spectrum.
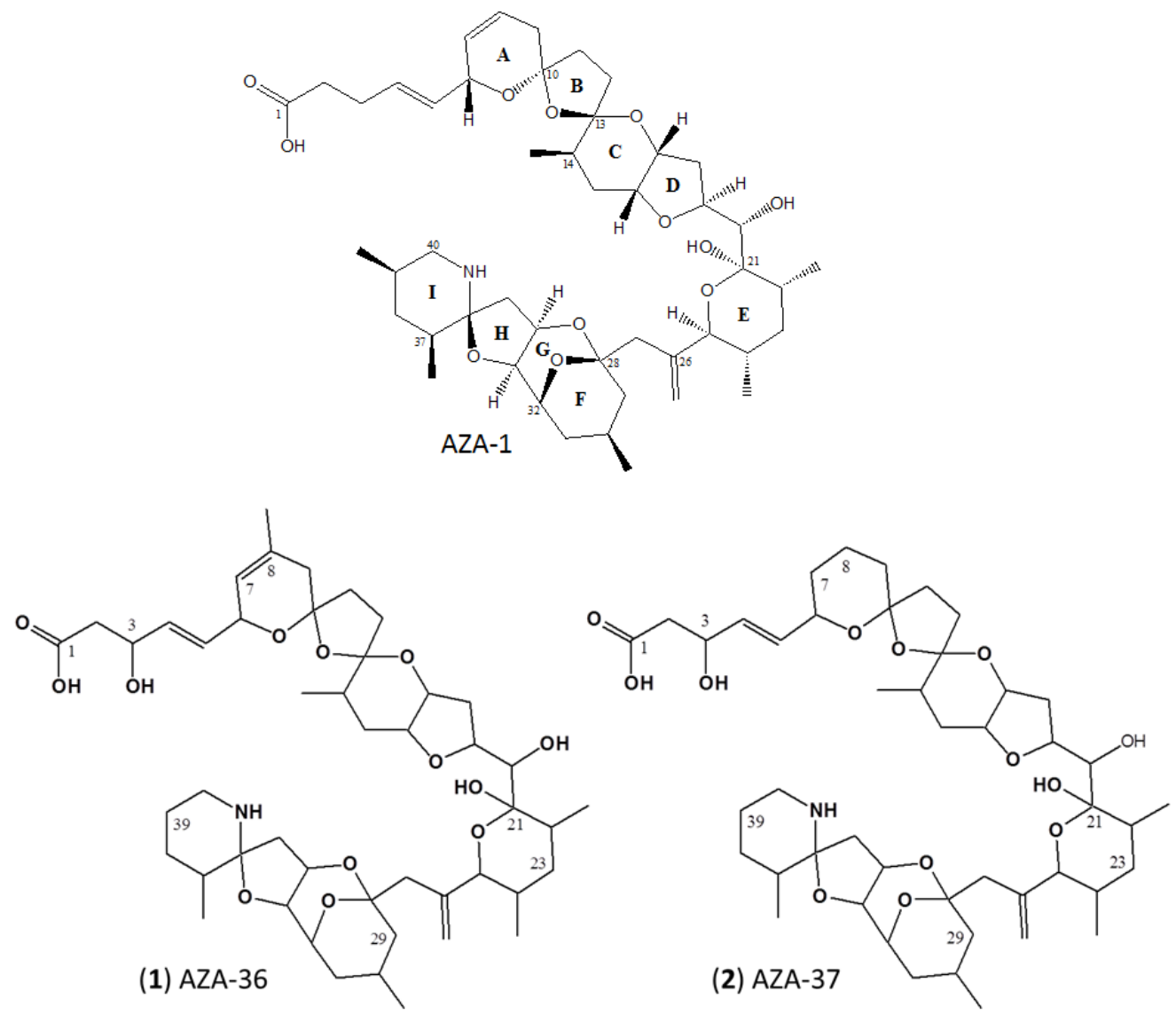

Figure 1. Structures of AZA-1 (top), AZA-36 (1) (bottom, left), and AZA-37 (2) (bottom, right).

The ${ }^{13} \mathrm{C}$-NMR spectrum of (2) showed four olefinic carbons in total, which are two less compared to AZA-1. After examination of the NMR spectra, it was concluded that the four olefinic carbons of (2) (C-4, C-5, C-26, and C-44) remained the same as in AZA-1. Therefore, the last double bond of AZA-1 at C-7/C-8 is a single bond in (2). Moreover, the new oxymethine signal at $\delta 4.39$ and loss of the 39-Me signal were also observed from the ${ }^{1} \mathrm{H}-\mathrm{NMR}$ spectrum. These data suggested the same 
hydroxylated carbon C-3 and the proton substituted methyl group at C-39 in (1). Therefore, the structure of AZA-37 was confirmed to be 3-hydroxy-7,8-dihydro-39-demethyl-azaspiracid-1 (2), as shown in Figure 1.

\subsection{Cytotoxicity}

The toxicity of (1) and (2) was assessed using the Jurkat $T$ lymphocyte cell assay. In order to compare this data to the known toxicities of other AZAs, AZA-1 was included in this assay and individual toxicities were expressed as relative potencies. Similar to AZA-1, (1) and (2) elicited concentration- and time-dependent cytotoxic effects towards $\mathrm{T}$ lymphocytes but with variable potencies, clearly seen from the dose-response curves of the three compounds (Figure 2). The cytotoxic effects induced by AZA-1 are consistent with previously published studies [31-33].
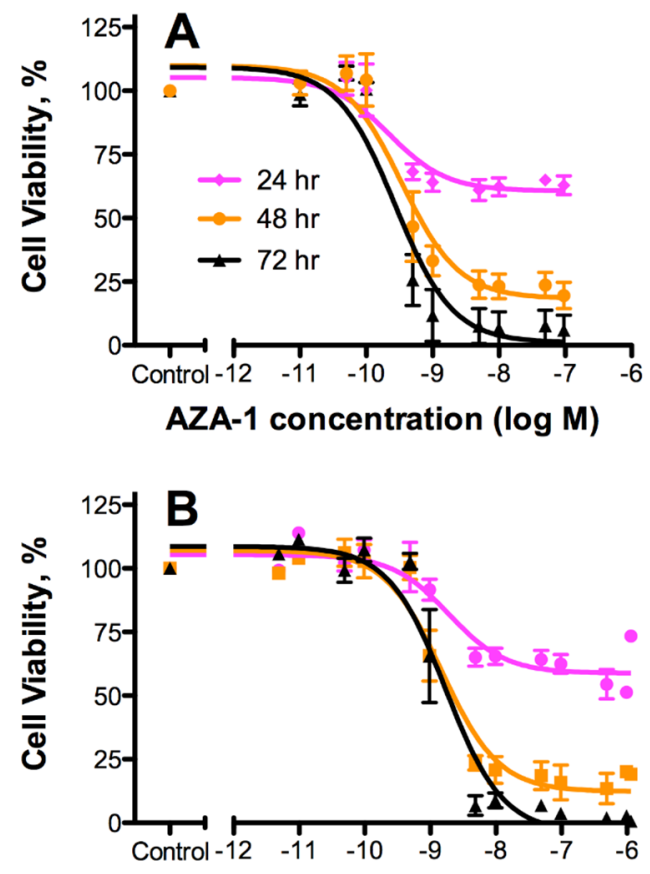

AZA-36 concentration (log M)

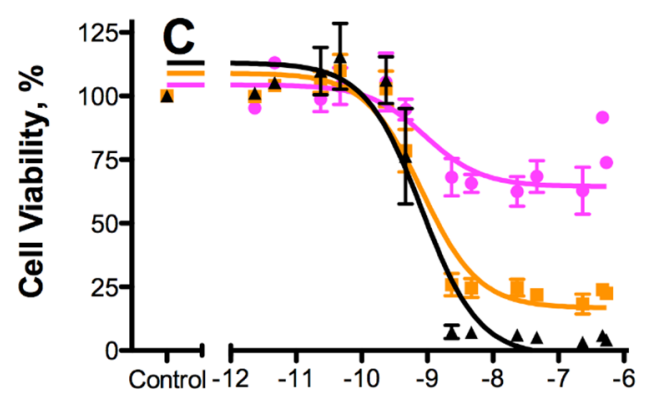

AZA-37 concentration ( $\log M)$

Figure 2. Effect on $\mathrm{T}$ lymphocyte cell viability. Jurkat $\mathrm{T}$ cells exposed to various concentrations of (A) AZA-1; (B) AZA-36 (1); and (C) AZA-37 (2) for 24, 48, or $72 \mathrm{~h}$ and viability assessed using the MTS assay. All data (mean $\pm \mathrm{SE} ; n=4$ ) were normalized to the control (10\% methanol vehicle). Non-linear, three parameter dose-response (variable slope) analysis was performed and $\mathrm{EC}_{50}$ values were calculated (Table 4). 
The steep slopes illustrate the narrow toxicological window and the step-wise decrease in viability with longer exposure times (at the higher concentrations) may represent the irreversible nature of the AZAs [34]. Compound (1) was found to be the least toxic with a relative (to AZA-1) toxicity of 16\% (mean EC50:1.70 nM) while (2) had a relative toxicity of 33\% (mean EC50: $0.85 \mathrm{nM}$ ) (Table 4).

Table 4. Calculated $\mathrm{EC}_{50}$ values (with $95 \%$ confidence intervals) and relative potencies for AZA-1, AZA-36 (1), and AZA-37 (2) based on a T lymphocyte cytotoxicity assay.

\begin{tabular}{|c|c|c|c|c|c|c|c|c|}
\hline \multirow{2}{*}{$\begin{array}{c}\text { AZA } \\
\text { Analogue }\end{array}$} & \multicolumn{2}{|c|}{$24 \mathrm{~h}$} & \multicolumn{2}{|c|}{$48 \mathrm{~h}$} & \multicolumn{2}{|c|}{$72 \mathrm{~h}$} & \multirow{2}{*}{$\begin{array}{c}\text { Mean } \\
\text { EC }_{50}[\mathrm{nM}]\end{array}$} & \multirow{2}{*}{ Rel. Pot } \\
\hline & $\mathrm{EC}_{50}[\mathrm{nM}]$ & $95 \%$ CI & $\mathrm{EC}_{50}[\mathrm{nM}]$ & $95 \%$ CI & $\mathrm{EC}_{50}[\mathrm{nM}]$ & $95 \% \mathrm{CI}$ & & \\
\hline AZA-1 & 0.22 & $0.10-0.49$ & 0.34 & $0.18-0.65$ & 0.27 & $0.14-0.52$ & 0.28 & 1 \\
\hline AZA-36* (1) & 1.9 & $0.89-4.1$ & 1.5 & $0.92-2.4$ & 1.7 & $0.92-3.2$ & 1.70 & 0.16 \\
\hline AZA-37 (2) & 0.91 & $0.27-3.1$ & 0.82 & $0.51-1.3$ & 0.82 & $0.46-1.5$ & 0.85 & 0.33 \\
\hline
\end{tabular}

* Data corrected for $97 \%$ purity.

\section{Discussion}

For many years, the causative organism responsible for the production of AZAs went unidentified. Since the discovery of $A$. spinosum in 2007, many new species have been identified. However, production of AZAs and the diversity and uniqueness of the various analogues has not yet been fully characterized for some of the recently identified Azadinium species. In the original species description, A. poporum was considered as non-toxic [22], but recent research showed that this dinoflagellate is capable of producing AZAs [30]. However, initial mass spectral data indicated that some of the AZAs produced by $A$. poporum were structurally unique from previously reported analogues by having a modification of the nitrogen-containing I-ring of the molecule [29,30,35]. The sum formula of (1) had previously been determined by high resolution mass spectrometry as $\mathrm{C}_{47} \mathrm{H}_{72} \mathrm{NO}_{13}$ and the elemental composition of (2) had been determined as $\mathrm{C}_{46} \mathrm{H}_{72} \mathrm{NO}_{13}$ [30]. Mass spectral interpretations of collision induced dissociation spectra allowed for the above mentioned structural predictions. However, these predictions are limited by the fact that mass spectrometry only yields the $m / z$ ratios of the fragments. Thus, mass spectrometry cannot differentiate between isomeric partial structures and full structural elucidation must be achieved by NMR. However, unlike mass spectrometry, NMR requires pure compounds in relatively high amounts (typically between 100 and $1000 \mu \mathrm{g}$ ). For this reason, we purified (1) and (2) from two strains of A. poporum, one from the western Pacific [28] and the other from the North Sea [22]. The standard procedure of extracting harvested cells with organic solvents results in extracts contaminated with a high proportion of matrix compounds, which require many purification steps. In the current study, the extraction protocol included acetone for cell lysis followed by the (SPATT) technique [36] for the extraction of AZAs. This approach was used previously by Jauffrais et al. [19] to harvest AZAs from the permeate and non-retentate phases following bulk culturing of A. spinosum in photobioreactors. The procedure does not require centrifugation or cell filtration steps, which makes it much more feasible. Only four isolation steps were required to purify (1) from the HP20 extracts. In contrast, for the isolation of (2) only three purification steps were necessary and the ethyl acetate-water liquid-liquid partitioning used in the purification of (1) could be omitted. Accordingly, (2) was purified by silica chromatography, flash chromatography, and preparative reversed phase chromatography (Table 2). 


\subsection{Structure Elucidation of AZA-36 (1) and AZA-37 (2)}

The results of the NMR investigation did not entirely confirm the originally proposed structures of (1) and (2) which were solely based on mass spectral experiments. The structural element that was confirmed is the 39-demethylation of the I-ring in both compounds in comparison to the parent compound AZA-1 (Figure 1). However, the NMR measurements of this study revealed that the hydroxylation site of both (1) and (2) is located at C-3 instead of the initially proposed C-2 position. In addition, the methyl group of the side chain/A-ring fragment of (1) is now known to be located at the C-8 position (instead of the initially proposed C-3 position), a feature shared by both (1) and AZA-2. Thus, we could unambiguously assign the structure of 3-hydroxy-8-methyl-39-demethyl-azaspiracid-1 to (1).

The structural elements of (2), which could be confirmed by NMR, are the above-mentioned 39-demethylation and additionally the 7,8-dihydration. However, the originally suggested 2-hydroxylation is now known to be at the $\mathrm{C}-3$ position and the 3-methylation at C-14 in the C-ring. Collectively, (2) is structurally elucidated as 3-hydroxy-7,8-dihydro-39-demethyl-azaspiracid-1 (Figure 1). It is noteworthy that both compounds, with the exception of the 39-demethylation, only show modifications in the side chain and A-ring of the molecule, which is the putative biosynthetic end of AZAs [37].

\subsection{Cytotoxicity}

Our cytotoxicity assays indicated that (1) and (2) are 6- and 3-fold less toxic than AZA-1 respectively. Both, (1) and (2) differ from AZA-1 in the lack of the 39-methyl group and in the additional 3-hydroxyl group. Most likely one of the two or even both structural elements seem to have an influence on the toxic potency in the T lymphocyte cell model system. Using the same cytotoxicity method with $\mathrm{T}$ lymphocyte cells, the relative cytotoxic potencies of naturally isolated AZA-1, AZA-2, and AZA-3 towards T lymphocytes was AZA-2 > AZA-3 > AZA-1 [31] strongly suggesting that methylation at the $\mathrm{C}-8$ and $\mathrm{C}-22$ positions play a role in determining the toxicity. Although the toxicophore of the AZA molecule has not yet been identified, the $\mathrm{A} / \mathrm{B} / \mathrm{C}$ ring region of the $\mathrm{AZA}$ molecule is highly important for maintained cytotoxicity. AZA-33 with an $m / z$ of 716 (AZA-1 missing $\mathrm{A} / \mathrm{B} / \mathrm{C}$ rings) was significantly less potent than AZA-1 ( $\sim 5$-fold), whereas AZA-34 with an $m / z$ of 816 (AZA-1 missing C4/C5 alkene) was 5.5-fold more potent than AZA-1 [20]. Similarly, an AZA-1 isomer (37-epi-AZA-1) was 5.1-fold more potent than AZA-1 [38]. Semi-synthetic hydrogenated AZA-1 analogues, 4,5-dihydro-AZA-1 and 4,5,7,8-tetrahydro-AZA-1, were also tested. Both compounds were found to be approximately equipotent to AZA-1 [32] suggesting that the C4/C5 alkene and the $\mathrm{C} 7 / \mathrm{C} 8$ olefin bonds are not necessary for toxicological activity.

\section{Experimental Section}

\subsection{Reagents}

Acetone and methanol used for cell lysis and resin preconditioning were HPLC grade, purchased from J.T. Baker (Center Valley, PA, USA). The anion exchange resin (Diaion ${ }^{\circledR}$ HP20) was from Supelco $^{\circledR}$ (Steinheim, Germany). All other solvents (pestican grade) were purchased from Labscan (Dublin, Ireland). Sodium chloride ( $>99 \%)$, triethylamine (99\%), ammonium acetate (>97\%), 
ammonium formate (reagent grade), formic acid (>98\%), and silica gel (10-40 $\mu \mathrm{m}$, type H) were purchased from Sigma-Aldrich (Steinheim, Germany). Luna Phenyl-Hexyl (15 $\mu \mathrm{m})$ was from Phenomenex (Cheshire, UK). AZA-1 certified reference material (CRM) was obtained from the NRC, Certified Reference Material Program (Halifax, NS, Canada).

\subsection{Cell Culture and Extraction}

A total of $870 \mathrm{~L}$ A. poporum strain HJ-2010 (hereafter named "Korea") isolated as described in [28] from Shiwha Bay, a highly eutrophic bay from Korea $\left(37^{\circ} 18^{\prime} \mathrm{N}, 126^{\circ} 36^{\prime} \mathrm{E}\right)$, and a total of $120 \mathrm{~L}$ A. poporum strain UTHC8 (hereafter named "North Sea") isolated from the North Sea [22] were cultivated in aerated $10 \mathrm{~L}$ batch cultures in F/2 medium-Si [39] (for the Korean isolate) or in a half-strength modified K-medium [22] (for the North Sea isolate) in a growth chamber at $20{ }^{\circ} \mathrm{C}$ under an illumination of $20-50 \mu \mathrm{E} \cdot \mathrm{m}^{-2} \cdot \mathrm{s}^{-1}$ of cool white fluorescent light on a 14:10 h light-dark cycle. Cultures were harvested in late stationary phase at cell densities (irregularly checked by manual counting using an inverted microscope) ranging from about $1-3 \times 10^{5}$ cell $\cdot \mathrm{mL}^{-1}$. Cells in the culture flasks were lysed by addition of acetone (HPLC grade, J.T. Baker, Center Valley, PA, USA) to final concentration of 7\%. One g $\cdot \mathrm{L}^{-1}$ anion exchange resin (Diaion ${ }^{\circledR} \mathrm{HP} 20$, Supelco ${ }^{\circledR}$, Steinheim, Germany), which previously had been preconditioned with methanol (HPLC grade, J.T. Baker, Center Valley, PA, USA) for $24 \mathrm{~h}$, was added to the broth. After shaking for $24 \mathrm{~h}$, the resin was then collected on a 100 $\mu \mathrm{m}$ Nitex mesh, dried, and frozen at $-20{ }^{\circ} \mathrm{C}$ until extraction. For extraction, $300 \mathrm{~g}$ of HP20 resin were suspended in $400 \mathrm{~mL}$ of methanol and shaken for $2 \mathrm{~h}$ on a lab shaker and subsequently partitioned into two aliquots. Each aliquot was transferred into a glass chromatography column $(3 \mathrm{~cm}$ diameter, $60 \mathrm{~cm}$ length) and was eluted with $500 \mathrm{~mL}$ methanol. The column elutes of each strain were reduced in a rotary evaporator, combined, and finally taken to dryness.

\subsection{Purification of $A Z A-36$ and $A Z A-37$}

The combined HP20 resin extracts were partitioned between ethyl acetate $(150 \mathrm{~mL})$ and aqueous $\mathrm{NaCl}(1 \mathrm{M}, 50 \mathrm{~mL})$. The ethyl acetate fraction was evaporated to dryness in vacuo. Approximately $2 \mathrm{~g}$ of silica gel was added to the dried extract. The sample was mixed to a fine powder and loaded on to a silica gel $(6 \mathrm{~g})$ column $(6 \times 4 \mathrm{~cm})$. Vacuum-assisted elution was performed successively with hexane, ethyl acetate, ethyl acetate-methanol (9:1, 7:3, and 1:1), and methanol (30 mL of each, all containing $0.1 \%$ acetic acid except for hexane). The methanol fraction, which flow injection analysis (FIA)-MS/MS (method A) showed to contain the AZAs, was evaporated in vacuo, and the sample in acetonitrile-water $(6: 4$, plus $0.1 \%$ triethylamine) was loaded onto a column packed with phenyl-hexyl $(19.9 \times 2 \mathrm{~cm})$. The sample was eluted with acetonitrile-water $(3: 7$, plus $0.1 \%$ triethylamine $)$ at $4 \mathrm{~mL} \cdot \mathrm{min}^{-1}$, and $5 \mathrm{~mL}$ fractions were collected. Appropriate fractions were combined (fractions 18-25 for AZA-36 (1) and fractions 17-23 for (2)) based on FIA-MS/MS analysis.

Final purification was achieved by semi-preparative model 10AVp HPLC (Shimadzu, Kyoto, Japan) with photodiode array (PDA) detection (210 nm) using a Cosmosil C18 (5 $\mu \mathrm{m}, 250 \times 4.6 \mathrm{~mm}$, Nacalai tesque, Kyoto, Japan) column eluted with acetonitrile--water (2:3, plus $2 \mathrm{mM}$ ammonium acetate) at $1 \mathrm{~mL} \mathrm{~min}{ }^{-1}$. The column temperature was $30^{\circ} \mathrm{C}$. Purified (1) was recovered by evaporation to $\sim 20 \%$ acetonitrile, loading on to a SPE cartridge (Oasis HLB, $200 \mathrm{mg}$ ), washing with 
methanol-water $(1: 9,10 \mathrm{~mL})$ to remove the buffer, and eluting with methanol-water $(4: 6,6: 4,8: 2$, 10:0, $20 \mathrm{~mL}$ each) with $>95 \%$ of the AZAs eluting in the 8:2 fraction. Removal of solvent by evaporation in vacuo afforded purified (1) and (2) as white solids.

\subsection{LC-MS/MS Analysis}

\subsubsection{Method A}

Qualitative analysis of fractions for AZAs was performed by FIA-MS/MS using a Micromass (Manchester, UK) QTof Ultima. Samples $(2 \mu \mathrm{L})$ were injected, using a Waters (Manchester, UK) model 2795 LC autosampler, directly (no column) into the mass spectrometer monitoring for the precursor ions: (1) $\mathrm{m} / \mathrm{z} 858.5$, and (2) $\mathrm{m} / \mathrm{z} 846.5$. The cone voltage was $40 \mathrm{~V}$, the cone and desolvation gas flows were set at 100 and $800 \mathrm{~L} \cdot h^{-1}$, respectively, and the source temperature was $150{ }^{\circ} \mathrm{C}$.

\subsubsection{Method B}

Recoveries were determined by quantitative analysis (against AZA-1 CRM) of fractions on a Waters 2795 LC coupled to a Micromass QTof Ultima operated in precursor ion scan mode monitoring for the following masses: AZA-1 $\mathrm{m} / \mathrm{z}$ 842.5, (1) $\mathrm{m} / \mathrm{z}$ 858.5, and (2) $\mathrm{m} / \mathrm{z}$ 846.5. The MS parameters were the same as those described in method A.

An isocratic elution was used, with phase A consisting of water and phase B of $95 \%$ acetonitrile in water (both containing $2 \mathrm{mM}$ ammonium formate and $50 \mathrm{mM}$ formic acid). Chromatography was performed with an ACE C18 column $(30 \times 2.1 \mathrm{~mm}, 3 \mu \mathrm{m})$ (Advanced Chromatography Solutions, Aberdeen, UK). The injection volume was $5 \mu \mathrm{L}$ and the column and sample temperatures were $25{ }^{\circ} \mathrm{C}$ and $6{ }^{\circ} \mathrm{C}$, respectively.

\subsubsection{Method C}

Purity was initially assessed on the QTof Ultima by running MS scans ( $m / z$ 100-1000) using binary gradient chromatographic conditions with phase A consisting of water and phase B of $95 \%$ acetonitrile in water (both containing $2 \mathrm{mM}$ ammonium formate and $50 \mathrm{mM}$ formic acid). Chromatography was performed with a Hypersil BDS C8 column $(50 \times 2.1 \mathrm{~mm}, 3 \mu \mathrm{m}$, with a $10 \times 2.1 \mathrm{~mm}$ guard column of the same stationary phase) (Thermo Scientific, Waltham, MA, USA). The gradient was from 30\% B, to $90 \% \mathrm{~B}$ over $8 \mathrm{~min}$ at $0.25 \mathrm{~mL} \cdot \mathrm{min}^{-1}$, held for $5 \mathrm{~min}$, then held at $100 \% \mathrm{~B}$ at $0.4 \mathrm{~mL} \mathrm{~min}{ }^{-1}$ for $5 \mathrm{~min}$, and returned to the initial conditions and held for $4 \mathrm{~min}$ to equilibrate the system. The injection volume was $5 \mu \mathrm{L}$ and the column and sample temperatures were 25 and $6{ }^{\circ} \mathrm{C}$, respectively. Analysis for other known AZA analogues was also performed by product ion scans, where the precursor ions were selected and then fragmented.

\subsubsection{Method D}

Purity was further assessed by UV analysis. A concentrated sample $\left(\sim 500 \mu \mathrm{g} \cdot \mathrm{mL}^{-1}\right)$ was injected $(1 \mu \mathrm{L}$ ) onto the semi preparative system (model 10AVp, Shimadzu, Kyoto, Japan) with photodiode array (PDA) detection $(210 \mathrm{~nm})$ using a Cosmosil C18 column $(5 \mu \mathrm{m}, 250 \times 4.6 \mathrm{~mm})$ eluted with 
acetonitrile-water $\left(2: 3\right.$, plus $2 \mathrm{mM}$ ammonium acetate) at $1 \mathrm{~mL} \cdot \mathrm{min}^{-1}$. The column temperature was $30{ }^{\circ} \mathrm{C}$.

\subsection{NMR Analysis}

NMR spectra were recorded on an Avance $600 \mathrm{MHz}$ NMR spectrometer (Bruker, Bremen, Germany) (600 MHz for ${ }^{1} \mathrm{H}, 150 \mathrm{MHz}$ for ${ }^{13} \mathrm{C}$ ) equipped with a cryo platform. All experiments were measured at $303 \mathrm{~K}$. Compounds (1) and (2) were obtained as white powders and dissolved in methanol- $d_{4}$ (3.31 ppm of residual $\mathrm{CH}_{3} \mathrm{OH}$ for ${ }^{1} \mathrm{H}-\mathrm{NMR}$ and $49.0 \mathrm{ppm}$ for ${ }^{13} \mathrm{C}-\mathrm{NMR}$ ). The spectra were all referred to solvent signals stated accordingly as internal standards.

\subsection{Toxicity Assays}

\subsubsection{Cell Culturing}

Human Jurkat E6-1 T lymphocyte cells (American Type Culture Collection TIB-152; Manassas, VA, USA) were grown as previously described [31]. Briefly, cells were grown in RPMI-1640 medium (cat. \#11875-093, Invitrogen, CA, USA) supplemented with 10\% (v/v) fetal bovine serum (FBS; cat. \#26140, Invitrogen, CA, USA) and maintained in a humidified incubator (18AIC-UV, Sanyo, Rutherford, NJ, USA) with 5\%:95\% $\mathrm{CO}_{2}$ :air at $37{ }^{\circ} \mathrm{C}$. Cells were subcultured with fresh medium at an inoculum ratio of 1:4 every 3 to 4 days by transferring $2.5 \mathrm{~mL}$ of cells to $7.5 \mathrm{~mL}$ of fresh supplemented medium in $75 \mathrm{~cm}^{2}$ screw cap culture flasks.

\subsubsection{Cytotoxicity Assay}

To determine the effect of the AZA analogues on cellular toxicity, Jurkat T lymphocyte cells were continuously exposed to toxins and viability determined. Exponentially growing cells were seeded in a volume of $100 \mu \mathrm{L}$ of the supplemented medium at a density of 30,000 cells per well in black, sterile, 96-well culture plates for 18-24 h to allow for recovery and settling. A range of final AZA concentrations were then added for 24,48 , or $72 \mathrm{~h}$ of continuous exposure prior to assessment of cytotoxicity. Parallel controls of equivalent amounts of methanol/PBS were used to normalize the viability data for each treatment. Cellular viability/cytotoxicity was assessed using the MTS (3-(4,5-dimethylthiazol-2-yl)-5-(3-carboxymethoxyphenyl)-2-(4-sulfophenyl)-2H-tetrazolium) assay (Promega Biosciences, San Luis Obispo, CA, USA; cat. no. G5421). Like other tetrazolium-based assays, MTS in the presence of an electron coupling reagent (phenazine methosulfate; PMS) measures cellular viability by determining the activity of mitochondrial dehydrogenases [40]. As a substrate for dehydrogenases, MTS becomes reduced into a soluble, purple dye that can be quantified colourimetrically to determine the relative level of cellular viability/cytotoxicity per well. Following exposure of the cells to the AZA analogues for a specified period of time, each well received $10 \mu \mathrm{L}$ of a PMS/MTS (1:20) solution. Cells were incubated for $4 \mathrm{~h}$ after which absorbance readings at $485 \mathrm{~nm}$ were obtained using a FluoStar microplate reader (BMG Lab Technologies, Cary, NC, USA). Data are presented as means \pm SE of three separate experiments ( $n=3$ biological replicates). In addition, within each experiment, every concentration of each AZA analogue was tested in duplicate wells. Cytotoxicity data were blank corrected and normalized to the control (\% viability). EC 50 and 95\% 
confidence interval determinations were calculated using three parameter, variable slope, non-linear regression analysis (GraphPad Prism, ver. 5.0f, San Diego, CA, USA). All data (mean \pm SE; $n=4)$ were normalized to the control (10\% methanol vehicle). Non-linear, three parameter dose-response (variable slope) analysis was performed and $\mathrm{EC}_{50}$ values were calculated (Table 4).

\section{Conclusions}

AZP events to date have only occurred with mussels harvested in Europe, which is consistent with the occurrence of the AZA-producing species A. spinosum in the Northeast Atlantic. However, we now have evidence that other species such as A. poporum and Amphidoma languida are also AZA-producers [30]. Whereas A. languida, to date, has only been confirmed to occur in the Northeast Atlantic, we now know that A. poporum has a much wider distribution [22,28,29]. Our data suggest that there is a potential risk of AZP in the North West Pacific area. The lower toxicity of AZA-36 is probably not the only reason for the lack of AZP events in the west Pacific, but environmental factors that control growth and proliferation of the producing species most likely also play an important role [41]. For this reason we suggest that AZA-36 and AZA-37 should be included in shellfish safety monitoring programmes. Currently both compounds can only be quantified as AZA-1 equivalents until standards for these compounds are made available. Although in vitro AZA-36 and AZA-37 are 6- and 3- fold less toxic than AZA-1, respectively, knowledge of the presence of these toxins in seafood, especially if associated with the presence of other shellfish toxins, is important for the health of shellfish consumers. Certainly more research is required to reveal the relationship between the occurrence of AZA-producers and AZP events.

\section{Acknowledgments}

Financial support was provided by the PACES research program of the AWI as part of the Helmholtz Foundation initiative in Earth and Environment. In addition, this study (Grant-Aid Agreement No. PBA/AF/08/001(01)) was partially carried out under the Sea Change strategy with the support of the Marine Institute and the Marine Research Sub-Programme of the National Development Plan 2007-2013, co-financed under the European Regional Development Fund. Éric Potvin was funded by the Fonds de Recherche du Québec - Nature et Technologies. This research was a part of the project titled "Korea-Polar Ocean in Rapid Transition (KOPRI, PM15040)", funded by the Ministry of Oceans and Fisheries, Korea and was also supported by the program on Management of Marine Organisms causing Ecological Disturbance and Harmful Effects of KIMST/MOF awarded to HJJ. Matthias Köck acknowledges the financial support from the Deutsche Forschungsgemeinschaft (DFG) under grants Ko 1314/5-1 and 5-2 (DFG-Forschergruppe FOR 934). The Ph.D. thesis of Q.G. was supported by this project. We thank Florian Pfaff for help with mass culturing and harvesting of A. poporum strains. 


\section{Author Contributions}

BK, UT, EP, HJJ, JK, MT and MK wrote the manuscript; UT and HJJ isolated the strains; EP and WD produced the biomass; JK purified the toxins; AAJ and MT performed the toxicity assays; and QG and MK performed NMR measurements and mass spectral interpretation.

\section{Conflicts of Interest}

The authors declare no conflict of interest.

\section{References}

1. McMahon, T.; Silke, J. West coast of Ireland; winter toxicity of unknown aetiology in mussels. Harmful Algae News 1996, 14, 2.

2. Satake, M.; Ofuji, K.; Naoki, H.; James, K.J.; Furey, A.; McMahon, T.; Silke, J.; Yasumoto, T. Azaspiracid, a new marine toxin having unique spiro ring assemblies, isolated from Irish mussels, Mytilus edulis. J. Am. Chem. Soc. 1998, 120, 9967-9968.

3. Nicolaou, K.C.; Frederick, M.O.; Petrovic, G.; Cole, K.P.; Loizidou, E.Z. Total synthesis and confirmation of the revised structures of azaspiracid-2 and azaspiracid-3. Angew. Chem. Int. Ed. 2006, 45, 2609-2615.

4. James, K.J.; Furey, A.; Satake, M.; Yasumoto, T. Azaspiracid Poisoning (AZP): A New Shellfish Toxic Syndrome in Europe, In Harmful Algal Blooms, Proceedings of the 9 International Conference on Harmful Algal Blooms, Hobart, Australia, 7-11 February 2000; Hallegraeff, G.M., Blackburn, S.I., Bolch, C.J.S., Lewis, R.J., Eds.; International Oceanogrphic Commission of UNESCO: Paris, France, 2000; pp. 250-253.

5. Lehane, M.; Braña-Magdalena, A.; Moroney, C.; Furey, A.; James, K.J. Liquid chromatography with electrospray ion trap mass spectrometry for the determination of five azaspiracids in shellfish. J. Chromatogr. A 2002, 950, 139-147.

6. Vale, P.; Bire, R.; Hess, P. Confirmation by LC-MS/MS of azaspiracids in shellfish from the Portuguese north-western coast. Toxicon 2008, 51, 1449-1456.

7. Taleb, H.; Vale, P.; Amanhir, R.; Benhadouch, A.; Sagou, R.; Chafik, A. First detection of azaspiracids in mussels in North West Africa. J. Shellfish Res. 2006, 25, 1067-1070.

8. Álvarez, G.; Uribe, E.; Ávalos, P.; Mariño, C.; Blanco, J. First identification of azaspiracid and spirolides in Mesodesma donacium and Mulinia edulis from Northern Chile. Toxicon 2010, 55, 638-641.

9. Ueoka, R.; Ito, A.; Izumikawa, M.; Maeda, S.; Takagi, M.; Shin-ya, K.; Yoshida, M.; Matsunaga, S.; van Soest, R.W.M.; Isolation of azaspiracid-2 from a marine sponge Echinoclathria sp. as a potent cytotoxin. Toxicon 2009, 53, 680-684.

10. Yao, J.; Tan, Z.; Zhou, D.; Guo, M.; Xing, L.; Yang, S. Determination of azaspiracid-1 in shellfish by liquid chromatography with tandem mass spectrometry. Chin. J. Chromatogr. 2010, 28, 363-367.

11. Vershinin, A.; Moruchkov, A.; Morton, S.L.; Leighfield, T.A.; Quilliam, M.A.; Ramsdell, J.S. Phytoplankton composition of the Kandalaksha Gulf, Russian White Sea: Dinophysis and lipophilic toxins in the blue mussel (Mytilus edulis). Harmful Algae 2006, 5, 558-564. 
12. Rehmann, N.; Hess, P.; Quilliam, M.A. Discovery of new analogs of the marine biotoxin azaspiracid in blue mussels Mytilus edulis by ultra-performance liquid chromatography/tandem mass spectrometry. Rapid Commun. Mass Spectrom. 2008, 22, 549-558.

13. Ofuji, K.; Satake, M.; McMahon, T.; Silke, J.; James, K.J.; Naoki, H.; Oshima, Y.; Yasumoto, T. Two analogs of azaspiracid isolated from mussels, Mytilus edulis, involved in human intoxication in Ireland. Nat. Toxins 1999, 7, 99-102.

14. Ofuji, K.; Satake, M.; McMahon, T.; James, K.J.; Naoki, H.; Oshima, Y.; Yasumoto, T. Structures of azaspiracid analogs, azaspiracid-4 and azaspiracid-5, causative toxins of azaspiracid poisoning in Europe. Biosci. Biotechnol. Biochem. 2001, 65, 740-742.

15. James, K.J.; Sierra, M.D.; Lehane, M.; Braña Magdalena, A.; Furey, A. Detection of five new hydroxyl analogues of azaspiracids in shellfish using multiple tandem mass spectrometry. Toxicon 2003, 41, 277-283.

16. Kilcoyne, J.; Keogh, A.; Clancy, G.; LeBlanc, P.; Burton, I.W.; Quilliam, M.A.; Hess, P.; Miles, C.O. Improved isolation procedure for azaspiracids from shellfish, structural elucidation of azaspiracid-6, and stability studies. J. Agric. Food Chem. 2012, 60, 2447-2455.

17. Krock, B.; Tillmann, U.; John, U.; Cembella, A.D. Characterization of azaspiracids in plankton size-fractions and isolation of an azaspiracid-producing dinoflagellate from the North Sea. Harmful Algae 2009, 8, 254-263.

18. Tillmann, U.; Elbrächter, M.; Krock, B.; John, U.; Cembella, A.D. Azadinium spinosum gen. et sp. nov. (Dinophyceae) identified as a primary producer of azaspiracid toxins. Eur. J. Phycol. 2009, $44,63-79$.

19. Jauffrais, T.; Kilcoyne, J.; Séchet, V.; Herrenknecht, C.; Truquet, P.; Hervé, F.; Bérard, J.B.; Nulty, C.; Taylor, S.; Tillmann, U.; et al. Production and isolation of azaspiracid-1 and-2 from Azadinium spinosum culture in pilot scale photobioreactors. Mar. Drugs 2012, 10, 1360-1382.

20. Kilcoyne, J.; Nulty, C.; Jauffrais, T.; McCarron, P.; Herve, F.; Foley, B.; Rise, F.; Crain, S.; Wilkins, A.L.; Twiner, M.J.; et al. Isolation, structure elucidation, relative LC-MS response, and in vitro toxicity of azaspiracids from the dinoflagellate Azadinium spinosum. J. Nat. Prod. 2014, 77, 2465-2474.

21. Tillmann, U.; Elbrächter, M.; John, U.; Krock, B.; Cembella, A.D. Azadinium obesum (Dinophyceae), a new nontoxic species in the genus that can produce azaspiracid toxins. Phycologia 2010, 49, 169-182.

22. Tillmann, U.; Elbrächter, M.; John, U.; Krock, B. A new non-toxic species in the dinoflagellate genus Azadinium: A. poporum sp. nov. Eur. J. Phycol. 2011, 46, 74-87.

23. Tillmann, U.; Soehner, S.; Nézan, E.; Krock, B. First record of the genus Azadinium (Dinophyceae) from the Shetland Islands, including the description of Azadinium polongum sp. nov. Harmful Algae 2012, 20, 142-155.

24. Akselman, R.; Negri, R.M. Blooms of Azadinium cf. spinosum Elbrächter et Tillmann (Dinophyceae) in northern shelf waters of Argentina, Southwestern Atlantic. Harmful Algae 2012, $19,30-38$.

25. Percopo, I.; Siano, R.; Rossi, R.; Soprano, V.; Sarno, D.; Zingone, A. A new potentially toxic Azadinium species (Dinophyceae) from the Mediterranean Sea, A. dexteroporum sp. nov. J. Phycol. 2013, 49, 950-966. 
26. Luo, Z.; Gu, H.; Krock, B.; Tillmann, U. Azadinium dalianense, a new dinoflagellate species from the Yellow Sea, China. Phycologia 2013, 52, 625-636.

27. Tillmann, U.; Gottschling, M.; Nézan, E.; Krock, B.; Bilien, G. Morphological and molecular characterization of three new Azadinium species (Amphidomataceae, Dinophyceae) from the Irminger Sea. Protist 2014, 165, 417-444.

28. Potvin, É.; Jeong, H.J.; Kang, N.S.; Tillmann, U.; Krock, B. First report of the photosynthetic dinoflagellate genus Azadinium in the Pacific Ocean: Morphology and molecular characterization of Azadinium cf. poporum. J. Eukaryot. Microbiol. 2012, 59, 145-156.

29. Gu, H.; Luo, Z.; Krock, B.; Witt, M.; Tillmann, U. Morphology, phylogeny and azaspiracid profile of Azadinium poporum (Dinophyceae) from the China Sea. Harmful Algae 2013, 21-22, 64-75.

30. Krock, B.; Tillmann, U.; Voß, D.; Koch, B.P.; Salas, R.; Witt, M.; Potvin, É.; Jeong, H.J. New azaspiracids in Amphidomataceae (Dinophyceae). Toxicon 2012, 60, 830-839.

31. Twiner, M.J.; El-Ladki, R.; Kilcoyne, J.; Doucette, G.J. Comparative effects of the marine algal toxins azaspiracid-1,-2, and-3 on Jurkat T lymphocyte cells. Chem. Res. Toxicol. 2012, 25, 747-754.

32. Kilcoyne, J.; Jauffrais, T.; Twiner, M.; Doucette, G.; Aasen Bunæs, J.A.; Sosa, S.; Krock, B.; Séchet, V.; Nulty, C.; Salas, R.; et al. Azaspiracids-Toxicological Evalution, Test Methods and Identification of the Source Organisms (ASTOX 2); Series, M.E.H., Ed.; Marine Institute: Galway, Ireland, 2014.

33. Twiner, M.J.; Hess, P.; Bottein Dechraoui, M.-Y.; McMahon, T.; Ramsdell, J.S.; Samons, M.S.; Satake, M.; Yasumoto, T.; Doucette, G.J. Cytotoxic and cytosketetal effects of azaspiracid-1 on mammalian cell lines. Toxicon 2005, 45, 891-900.

34. Twiner, M.J.; Rehmann, N.; Hess, P.; Doucette, G.J. Azaspiracid Shellfish Poisoning: A review on the chemistry, ecology, and toxicology with an emphasis on human health impacts. Mar. Drugs 2008, 6, 39-72.

35. Krock, B.; Tillmann, U.; Witt, M.; Gu, H. Azaspiracid variability of Azadinium poporum (Dinophyceae) from the China Sea. Harmful Algae 2014, 36, 22-28.

36. MacKenzie, L.; Beuzenberg, V.; Holland, P.; McNabb, P.; Selwood, A. Solid phase adsorption toxin tracking (SPATT): A new monitoring tool that simulates the biotoxin contamination of filter feeding bivalves. Toxicon 2004, 44, 901-918.

37. Rein, K.S.; Snyder, R.V. The biosynthesis of polyketide metabolites by dinoflagellates. In Advances in Applied Microbiology; Academic Press: San Diego, CA, USA, 2006; Volume 59, pp. 93-125.

38. Kilcoyne, J.; McCarron, P.; Twiner, M.J.; Nulty, C.; Crain, S.; Wilkins, A.; Rise, F.; Quilliam, M.A.; Miles, C.O. Epimers of azaspiracids: isolation, structural elucidation, relative LC-MS response, and in vitro toxicity of 37-epi-azaspiracid-1. Chem. Res. Toxicol. 2014, 27, 587-600.

39. Guillard, R.R.L.; Ryther, J.H. Studies on marine planktonic diatoms. I. Cyclotella nana Hustedt and Detonula confervaceae (Cleve) Gran. Can. J. Microbiol. 1962, 8, 229-239.

40. Mosmann, T. Rapid colorimetric assay for cellular growth and survival: Application to proliferation and cytotoxicity assays. J. Immunol. Methods 1983, 65, 55-63. 
41. Potvin, E.; Hwang, Y.J.; Yoo, Y.D.; Kim, J.S.; Jeong, H.J. Feeding by heterotrophic protists and copepods on the photosynthetic dinoflagellate Azadinium cf. poporum from western Korean waters. Aquat. Microb. Ecol. 2013, 68, 143-158.

(C) 2015 by the authors; licensee MDPI, Basel, Switzerland. This article is an open access article distributed under the terms and conditions of the Creative Commons Attribution license (http://creativecommons.org/licenses/by/4.0/). 